\section{Psicanálise em nova chave}

Isaias Melsohn. São Paulo: Editora Perspectiva, 2002, 360 págs. ISBN: 85-273-0266-7

Redimensionar o enigma, é o que nos sugere a capa do livro "Psicanálise em nova chave", de Isaias Melsohn, autor que busca expressar sua nova, mas não menos rigorosa, concepção sobre a questão do fundamento da psicanálise. Psiquiatra de formação e psicanalista de primeira hora, representante, por isso mesmo, das questões tratadas, parte das divergências entre a psiquiatria e a psicologia clássica, localizando com profunda objetividade os modelos teóricos do final do séc. XIX, assim como os novos princípios provenientes da emergência das ciências e que propiciarão a constituição da psicanálise como corpo doutrinário. Conhecedor perspicaz da concepção epistemológica moderna, identifica com propriedade o modelo de racionalidade empirista, como o estatuto teórico subjacente à concepção freudiana de inconsciente, explicitando também como essa teoria possibilita, a seu ver, o equívoco de Freud.

De imediato é preciso esclarecer: Isaias não opina. Não faz crítica ingênua.

Mergulhando com incrível rigor em nível conceitual, discute os estatutos epistemológicos contemporâneos, demonstrando detalhadamente sua crítica, enquanto constrói seu pensamento e impõe seu livro como obra de fundamento.

Isaias, como Freud, é pensador radical de seu tempo e se apropria do arcabouço fenomenológico instituído por Husserl, na primeira metade do século passado e desenvolvido pelas filosofia e psicologia das escolas alemã e francesa, e o integra às contribuições da lingüística e das novas ciências humanas. É com esse ferramental de revés que desmonta o alicerce percepção/representação da argumentação freudiana, que, tendo concebido a distinção entre as percepções consciente (da coisa mais da palavra correspondente) e inconsciente (da coisa), levou Freud a postular uma dimensão além da consciência, como depositário das representações destituídas de representações verbais e caráter lógico.

Em substituição a essa concepção consciente/inconsciente como recipiente da representação da coisa composta de atributos e determinações afetivas, Isaias explicita a consciência como forma estruturante de nossas vivências, como forma de apreensão afetiva, permeada pela linguagem de unidades expressivas de sentido. Da totalidade da experiên- cia expressiva, alguns elementos que se destacam são tomados como representativos, e por eles ela pode ser reconhecida. A experiência de constituição dos fenômenos é, portanto, dependente da apreensão dos sentidos emocionais primordiais que a consciência estrutura em sua função expressiva.

A partir de então, a concepção de inconsciente está em questão, bem como as práticas psicanalíticas que respectivamente visam o passado reprimido.

À psicanálise não cabe mais a bus-

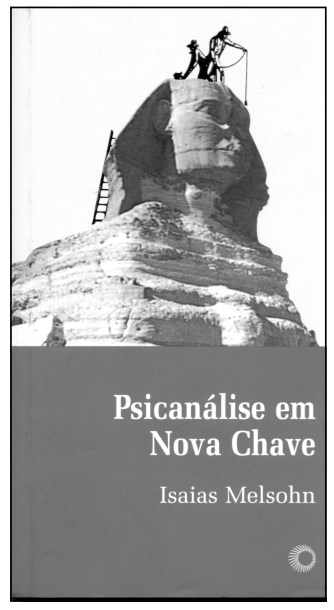
ca da representação cuja significação foi registrada no passado. Isto já não faz sentido. Ela deverá considerar no material da sessão o que está sendo expresso no presente, vivo, de sentido representado pela palavra. Porém, seu campo de observação não se restringe mais só ao discurso que revela o significado vivido, mas deve se estender a outras sintaxes, discursivas e não-discursivas, a todas as formas de expressão de sentido da experiência psíquica: fala, gestos, entonação, atitudes, comportamentos, sonhos, delírios, razões, devaneios.

Não por acaso, a linguagem é distinção humana. Na verdade, ela se impõe como elemento constitutivo do fenômeno expressivo e, portanto, do desenvolvimento mental, já que por ela é possível retomarmos fenômenos diferentes e distantes e nos introduzirmos no âmbito do pensamento e da realidade simbólica.

Assim, Isaias não pondera sobre a problemática da psicanálise, e talvez essa seja a origem do conflito com o International Journal of Psycho-Analysis, devidamente publicado. Debate com Freud, de dentro dela, como comprovam seus seminários clínicos. Desse encontro entre esses dois judeus, seria possível imaginar ouvir, quando apertassem as mãos com sorriso cúmplice, este dizer: "Valeu", no mesmo instante em que aquele diz: "Obrigado".

É disto que somos herdeiros, e é por isto que somos responsáveis, em nossas clínicas, por esse: "valeu/obrigado".

Ruth Borges Garcia dos Santos Psicanalista 